(-

OPEN ACCESS

\title{
Rapid hair depigmentation in patient treated with pazopanib
}

\author{
Robert Šeparović, ${ }^{1}$ Mirjana Pavlović, ${ }^{1}$ Tajana Silovski, ${ }^{2}$ Ana Tečić Vuger ${ }^{1}$
}

'Department of Medical Oncology, Klinicki Bolnicki centar Sestre milosrdnice, Zagreb, Croatia

${ }^{2}$ Department of Oncology, Klinicki Bolnicki Centar Zagreb, Zagreb, Croatia

\section{Correspondence to}

Ana Tečić Vuger,

ana.tecic@yahoo.com

Accepted 1 August 2018
Check for updates

(c) BMJ Publishing Group Limited 2018. Re-use permitted under CC BY-NC. No commercial re-use. See rights and permissions. Published by BMJ.

To cite: Šeparović $R$, Pavlović M, Silovski T, et al. BMJ Case Rep Published Online First: [please include Day Month Year] doi:10.1136/bcr-2018224209

\section{SUMMARY}

Pazopanib is multitargeted tyrosine kinase inhibitor used for the treatment of metastatic renal cell carcinoma. Hair colour change is a common side effect of pazopanib therapy which usually develops gradually during few months of therapy. We report a case of the patient who developed multiple pazopanib side effects followed by rapid overnight hair and eyebrow depigmentation after only few weeks of therapy. In our research, we found no literature data of rapid loss of hair pigment due to therapy with any of listed multitargeted tyrosine kinase inhibitors. To the best of our knowledge, this is the first such case being reported. We presume that summation of different mechanisms probably led to rapid hair depigmentation. Considering the fact that pazopanib treatment was very effective in our patient, this side effect could be a good predictor of therapy success, although it presents very stressful event for patient and his family.

\section{BACKGROUND}

Pazopanib is multitargeted tyrosine kinase inhibitor (TKI) that targets and inhibits vascular endothelial growth factor receptors, platelet-derived growth-factor receptors and the stem cell factor (SCF) receptor c-kit. This results in inhibition of tumour angiogenesis and cell proliferation, thereby preventing tumour growth. The therapeutic efficacy of pazopanib in patients with metasatic renal cell carcinoma (mRCC) has been demonstrated in several clinical trials. The most commonly reported adverse events were hypertension, diarrhoea, hair colour changes, anorexia and nausea. ${ }^{1}$ We report a case of a patient with mRCC who experienced rapid hair depigmentation during the second cycle of pazopanib.

\section{CASE PRESENTATION}

A 62-year-old man was referred to urology department due to left renal mass. Preoperative radiological evaluation showed expansive process of the left kidney with nodose lesions in both lungs. Patient underwent left-sided nephrectomy and was diagnosed with clear cell RCC with multiple pulmonary metastases (largest lesion measured $20 \mathrm{~mm}$ ). He was treated with pazopanib $4 \times 200 \mathrm{mg}$ once daily. During the first month of treatment, the patient developed grade III hypertension (up to 220/120 mm $\mathrm{Hg}$ ) which required discontinuation of pazopanib and modification of antihypertensive therapy. Over the next 2 weeks, blood pressure values normalised and pazopanib therapy was continued in the same dose $(800 \mathrm{mg}$, but different regimen $-2 \times 400 \mathrm{mg}$ ). After few days of therapy, the patient developed abdominal pain followed by nausea and vomiting for which he was admitted to hospital. During hospitalisation, the patient underwent multislice CT which showed regression of pulmonary metastases in size and number (largest lesion measured $12 \mathrm{~mm}$ ). He was treated symptomatically and his symptoms ceased. He continued treatment with pazopanib for two more days when he developed abdominal cramps, diarrhoea grade IIII and dysphonia. In the morning of the next day, the patient woke up and noticed that his hair and eyebrows turned completely white during the night (figures 1-3).

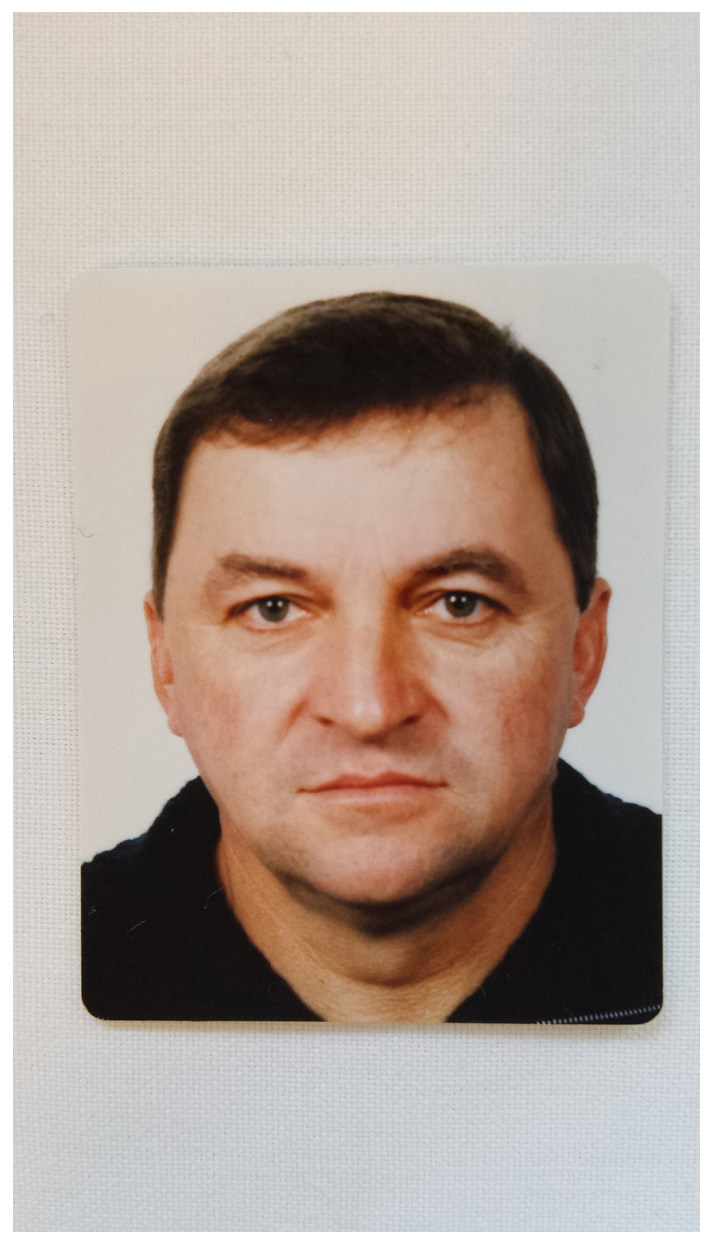

Figure 1 Patient prior to manifestation of adverse event described in the case report-rapid hair depigmentation. 


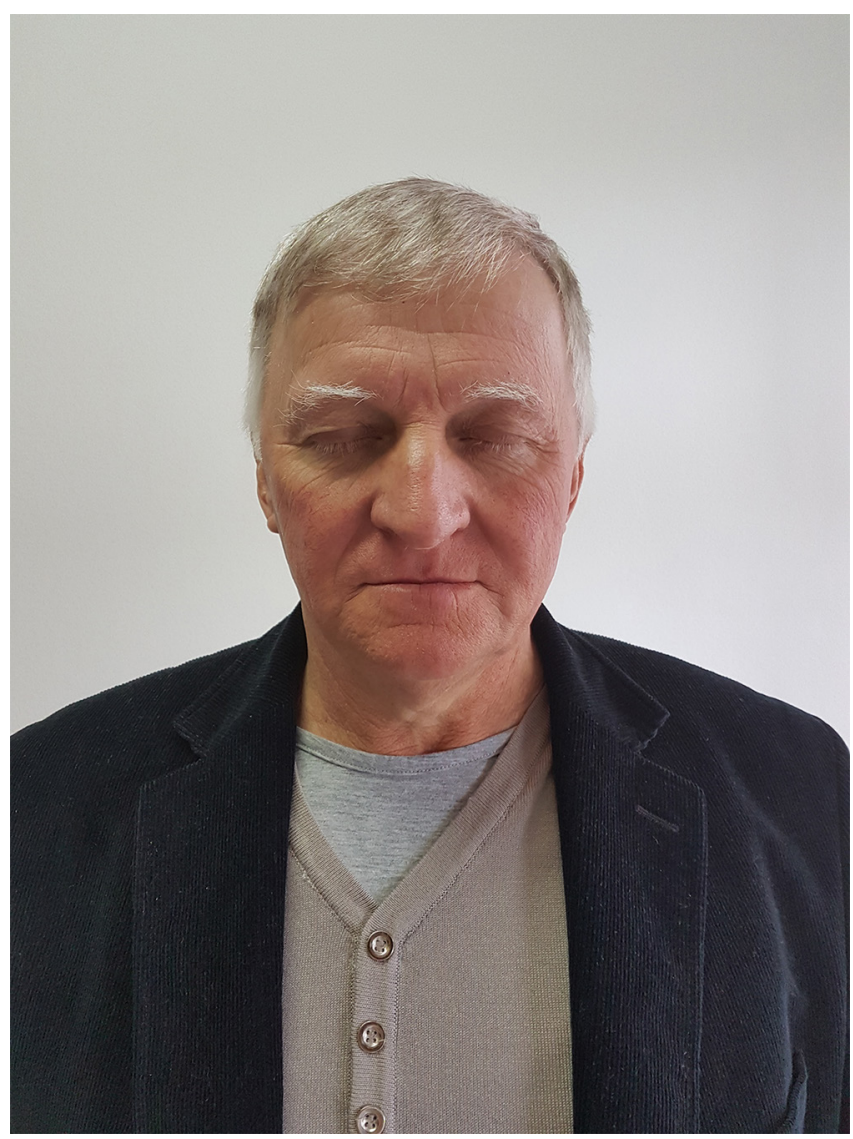

Figure 2 Patient after developing rapid hair depigmentation due to pazopanib-photo taken in anterior-posterior direction.

\section{TREATMENT}

He stopped using pazopanib and was again admitted to hospital where he was treated symptomatically. Discontinuation of pazopanib therapy lasted for 7 weeks until the patient recovered. His hair and eyebrows stayed white throughout this period. Therapy was started again in reduced dose of $2 \times 200 \mathrm{mg}$ once daily which patient tolerated well. After few weeks, pazopanib dose was increased to $3 \times 200 \mathrm{mg}$.

\section{OUTCOME AND FOLLOW-UP}

Control CT (performed 3 months after previous one) showed further regression of pulmonary metastases (largest lesion measured $8 \mathrm{~mm}$ ). Patient's hair and eyebrows gradually started to restore colour.

\section{DISCUSSION}

Hair pigmentation is regulated by several factors including SCF and its TKI c-kit whose normal interaction is required for maintenance of hair follicle melanocytes. ${ }^{2} \mathrm{SCF} / \mathrm{c}-\mathrm{kit}$ signalling pathway facilitates generation and migration of functional melanocytes during each new hair cycle, and it has been showed that different populations of the hair follicle melanocytes express different dependence on SCF during cyclic regeneration of the hair pigmentary unit. It has been described that mutation in either of these genes results in disorders which include hair depigmentation in mice and in humans. ${ }^{34}$ Hair depigmentation has been reported in response to therapy with multitargeted receptor TKIs such as sunitinib, pazopanib and imatinib due to their inhibition of c-kit. ${ }^{5}$ Reported incidence of hair colour changes in patient treated with pazopanib is about $35 \%$ according to drug-safety

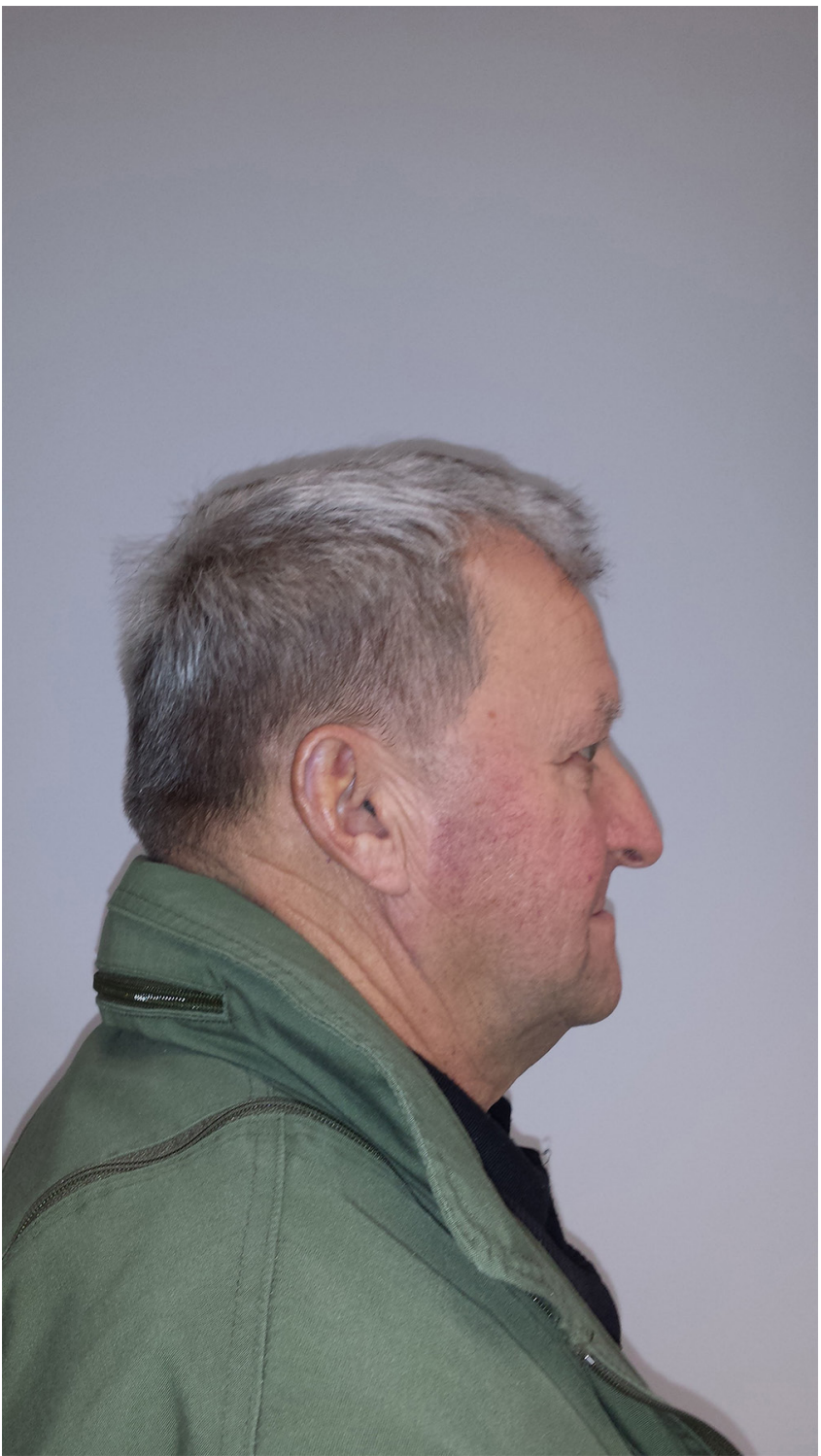

Figure 3 Patient after developing rapid hair depigmentation due to pazopanib_-photo taken in right profile.

studies. In a few reported cases, hypopigmentation was first noted after 1-5 cycles of therapy and it gradually developed to maximum after 6-10 cycles. ${ }^{7}$ In our research, we found no clinical or literature data of rapid (overnight) loss of hair pigment due to therapy with any of the listed multitargeted TKIs. To the best of our knowledge, this is the first such case being reported. Rapid loss of hair pigment is called canities subita, and throughout history it was documented in several patients (including some of which were famous historical figures), but exact mechanism of this phenomenon have still not been cleared. During our literature check, we came across an article published in International Journal of Trichology in which the authors reappraised cases of rapid hair depigmentation collected in medical literature from year 1800 until today. In total, they gathered 196 cases of which 44 was authenticated by physician who saw their patients before and after the colour change. All of the mentioned patients were found to be exposed to some kind of great physical, emotional or psychological stress shortly before change of colour occurred. ${ }^{8}$ Different assumptions about cause of rapid hair depigmentation were not scientifically confirmed until this 
day. Two most scientifically sustainable theories include one of alopecia areata diffusa which selectively impacts only pigmented hair and leave only grey hair on scalp which could be mistaken for rapid hair pigment loss (this could be a good explanation for elderly patient who already have greater amount of grey hair on their scalp) and second one implied on animal model where endocrine mechanism influences function of pineal gland and causes changes in melatonin excretion (it was scientifically proven that melatonin influences animal behaviour, reproduction and coat growth). ${ }^{9}$ Subsequent neuroendocrine mechanism was implied as cause of rapid hair depigmentation in one old case of 40-year-old patient whose hair became completely white, his testes became smaller and he lost his libido and potency, the following night after hypothalamic trauma. ${ }^{10}$

\section{Learning points}

- True pathophysiology of this phenomenon is still unclear and needs to be further investigated. In our case, we may assume that well-known influence of tyrosine kinase inhibitors (TKIs) on hair pigment was additionally emphasised by psychological distress and acute pain that our patient suffered at the time. We presume that that summation of different mechanisms probably led to rapid hair depigmentation.

- It is also important to note that, in our patient, pazopanib treatment was very effective with good regression of the disease, and so this phenomenon could be a good predictor of therapy success.

- Rapid hair discolouration was not yet described in relation with TKIs therapy; so it is important to keep in mind that such adverse event is possible. Exact pathophysiology of this phenomenon is still not clear and hopefully further scientific efforts will be made to help with understanding this, to patient, very stressful event.
Contributors All the authors contributed to creating a paper in a proportionate way to their position in the authors list. RŠ provided us with the idea of writing this case report, conception, gave a plan of action, reviewed the text when first version was prepared, gave all the necessary corrections, formed the final version of the text and wrote the final version of discussion. MP was patients physician; she wrote most of the case report and introduction and helped in writing discussion. TS reviewed the case report and wrote the first version of discussion. ATV acquired literature data and helped in writing introduction and discussion and submitted the article.

Funding The authors have not declared a specific grant for this research from any funding agency in the public, commercial or not-for-profit sectors.

Competing interests None declared.

Patient consent Next of kin consent obtained.

Provenance and peer review Not commissioned; externally peer reviewed.

Open access This is an open access article distributed in accordance with the Creative Commons Attribution Non Commercial (CC BY-NC 4.0) license, which permits others to distribute, remix, adapt, build upon this work non-commercially, and license their derivative works on different terms, provided the original work is properly cited and the use is non-commercial. See: http://creativecommons.org/ licenses/by-nc/4.0/

\section{REFERENCES}

1 Sternberg CN, Davis ID, Mardiak J, et al. Pazopanib in locally advanced or metastatic renal cell carcinoma: results of a randomized phase III trial. J Clin Oncol 2010;28:1061-8.

2 Schallreuter K, Slominski A, Pawelek JM, et al. What controls melanogenesis? Exp Dermatol 1998;7:143-50.

3 Botchkareva NV, Khlgatian M, Longley BJ, et al. SCF/c-kit signaling is required for cyclic regeneration of the hair pigmentation unit. Faseb J 2001;15:645-58.

4 Richards KA, Fukai K, Oiso N, et al. A novel KIT mutation results in piebaldism with progressive depigmentation. J Am Acad Dermatol 2001:44:288-92.

5 Hasan S, Dinh K, Lombardo F, et al. Hypopigmentation in an African patient treated with imatinib mesylate: a case report. J Nat/ Med Assoc 2003;95:722-4.

6 Sideras K, Menefee ME, Burton JK, et al. Profound hair and skin hypopigmentation in an African American woman treated with the multi-targeted tyrosine kinase inhibitor pazopanib. J Clin Oncol 2010;28:e312-3.

72010 ASCO Annual Meeting. Effect of pazopanib on hair and skin hypopigmentation: a series of three patients. I Clin Oncol 2010;28.

8 Nahm M, Navarini AA, Kelly EW, et al. Canities subita: a reappraisal of evidence based on 196 case reports published in the medical literature. Int J Trichology 2013;5:63-8.

9 Skellett AM, Millington GW, Levell NJ. Sudden whitening of the hair: an historical fiction? I R Soc Med 2008:101:574-6.

10 Ephraim AJ. On sudden or rapid whitening of the hair. Arch Dermatol 1959;79:228.

Copyright 2018 BMJ Publishing Group. All rights reserved. For permission to reuse any of this content visit

http://group.bmj.com/group/rights-licensing/permissions.

BMJ Case Report Fellows may re-use this article for personal use and teaching without any further permission.

Become a Fellow of BMJ Case Reports today and you can:

- Submit as many cases as you like

- Enjoy fast sympathetic peer review and rapid publication of accepted articles

- Access all the published articles

- Re-use any of the published material for personal use and teaching without further permission

For information on Institutional Fellowships contact consortiasales@bmjgroup.com

Visit casereports.bmj.com for more articles like this and to become a Fellow 